\title{
Spatial patterns and interactions of dominant tree species in an Amazon tropical rainforest
}

\author{
Vinicius Costa Cysneiros ${ }^{1}$, Cilmar Antônio Dalmaso ${ }^{2}$, Allan Libanio Pelissari ${ }^{1}$, \\ Patricia Povoa de Mattos ${ }^{3}$, Luizinho de Souza ${ }^{4} \&$ Sebastião do Amaral Machado ${ }^{1}$ \\ 1. Department of Forest Sciences, Federal University of Paraná (UFPR), Av. Professor Lothário Meissner, 632, Curitiba \\ - PR, Brazil, 80210-170; vccysneiros.florestal@gmail.com, allanpelissari@gmail.com, samachado@ufpr.br \\ 2. Department of Agrarian Sciences, Federal University of Paraná (UFPR), Rua dos Funcionários, 100, Curitiba - PR, \\ Brazil, 80035-050; cilmard@gmail.com \\ 3. Embrapa Florestas, Estrada da Ribeira, km 111, Colombo - PR, Brazil, 83411-000; patricia.mattos@embrapa.br \\ 4. Amata Brasil Company, Estrada da Balsa, km 1, Itapuã do Oeste - RO, Brazil, 76861-000; \\ luizinho.souza@amatabrasil.com.br \\ * Correspondence
}

Received 17-V-2018. Corrected 06-VII-2018. Accepted 08-VIII-2018.

\begin{abstract}
Knowledge of spatial patterns and interactions of tree species allows for understanding the ecological processes of spatiotemporal structures of tropical forests, becoming essential for the establishment of strategies for the conservation and management of their resources in the long term. The aim of this study was to investigate the spatial patterns and interactions of Astronium lecointei, Dinizia excelsa and Peltogyne paniculata, three dominant timber tree species in the Jamari National Forest, Rondônia, Brazilian Amazon. The Kernel estimator was used aiming to verify the possible influence of first-order factors on species distributions. Inhomogeneous $\mathrm{K}$-functions were applied to analyze species spatial patterns and interactions by means of second-order factors. Univariate analyses revealed different scale-dependent spatial patterns for the species. Aggregation related to ecological characteristics, such as habitat preference and dispersal limitation, was verified for A. lecointei and P. paniculata. D. excelsa presented a random spatial pattern, explained by specific features of its establishment, such as the need for clearings due to light requirements. Interspecific associations were evidenced by bivariate analyses, in which spatial attraction of species resulted from the same preference for microhabitats and the repulsion was a result of niche segregation. Rev. Biol. Trop. 66(3): 1009-1017. Epub 2018 September 01.
\end{abstract}

Key words: timber species; spatial distribution; interspecific associations; Kernel density estimator; inhomogeneous K-function.

Spatial patterns and interactions play a central role in many ecological theories of biological communities and populations (Legendre \& Fortín, 1989; Dale, 1999; Condit et al., 2000). Knowledge of these patterns and interactions allows understanding of the ecological processes of spatiotemporal structuring of tropical forests (Fangliang, Legendre, \& Lafrankie, 1997; Batista \& Maguire, 1998; Silva et al., 2014; Rockwell et al., 2017), becoming essential for the developing strategies for conservation and management of tree species in the long-term (Myster \& Malahy, 2012).
In tropical forests, several mechanisms contribute to aggregation of tree species, such as segregation of specific niches (Pielou, 1961), habitat heterogeneity (Harms, Condit, Hubbell, \& Forster, 2001), dispersal limitations (Hubbell, 2001), reproductive behavior, and type of predation (Janzen, 1970). The regular spatial patterns derive from the interaction between individuals, being less common in plant populations and communities (Fangliang, Legendre, \& Lafrankie, 1997), but found in allelopathic species that present biological inhibition or in environments with limited resource 
availability, where competition is intense due to the sites saturation (Silva, Martins, Santos, \& Ribeiro, 2009).

Random patterns represent the null hypothesis of most models described in the form of a point spatial process. In natural forests, the occurrence of this pattern implies in environmental homogeneity or lack of habitat specificity of the species (Matteucci \& Colma, 1982), and may be a consequence of antagonistic pressures such as illegal logging (Ricklefs \& Miller, 2000). Thus, several factors that influences the spatial distribution of tropical trees can be synthesized under two main effects: 1) first-order effects, which are global and of large scale, reflecting abiotic characteristics; and 2) second-order effects, which derive from the spatial dependence of a smallscale process, resulting from biotic interactions (Bailey \& Gatrell, 1995; Pottker, Oliveria, Figuereido, \& Dalmaso, 2016).

In plant communities, trees interact under diverse ways, making it easier or more difficult for the establishment of other trees (Callaway, 1995; Ewel \& Hiremath, 2005; Volkov, Banavar, \& Hubbel, 2009). Positive interactions have been investigated in several ecological systems, aiming mainly understanding the facilitation mechanisms (Callaway, 1995). On the other hand, negative interactions usually derive from competition and allelopathy (Connell, 1983; Crawley, 1986). These two types of interactions can bring spatial patterns of attraction or repulsion, which, once quantified, provide important evidence about the spatiotemporal dynamics of plant populations and communities (Callaway, 1995; Chen \& Bradshaw, 1999; Condit et al., 2000).

This study aims to investigate the spatial patterns and interactions of three dominant tree species in a Brazilian Amazon tropical rainforest, considering the effects of first- and second-order factors. Thus, we formulated the following questions: How are these species spatially distributed in the study area? Do the species have spatial patterns and interspecific interactions dependent on scale? Can spatial interactions between dominant trees in high-diversity forests be explained by overlap or segregation of habitats?

\section{MATERIAL AND METHODS}

Study area: This study was carried out in Jamari National Forest (Jamari FLONA), located in Rondônia State, North Brazil, between geographical coordinates $\left(09^{\circ} 00^{\prime} 00^{\prime \prime}\right.$ $09^{\circ} 30^{\prime} 00^{\prime}$ 'S \& $\left.62^{\circ} 44^{\prime} 05^{\prime \prime}-63^{\circ} 16^{\prime} 64^{\prime \prime} \mathrm{W}\right)$. The climate of the region is rainy tropical, type Aw (Köppen), with a dry period well defined in the winter season and average annual precipitation around $2400 \mathrm{~mm}$ (Alvares, Stape, Sentelhas, de Moaes Gonçalves, \& Sparovek, 2013). Dense and open tropical rainforest typologies predominate in the region.

Flona do Jamari was the first public forest in Brazil to adopt the governments's system of forest concession for lumber production through Sustainable Forest Management (Bauch, Sills, Rodríguez, Mcginley, \& Cubbage, 2009). The said forest is characterized by large diversity and richness of species with commercial size which occupy the upper levels and clear dominance of some lumber species (Péllico Netto, Pelissari, Cysneiros, Bonazza, \& Sanquetta, 2017).

Database: We used an unlogged Production Unit to evaluate the patterns and special interactions of dominant species under natural conditions, in the forest, without interventions. We used populations data of the following timber species: Astronium lecointei Ducke (Anacardiaceae), with 1296 trees; Dinizia excelsa Ducke (Fabaceae), with 986 trees; and Peltogyne paniculata Benth. (Fabaceae), with 1598 trees. Data were obtained from forest census of 1596 ha, carried out in the year 2015, where 17551 trees with DBH (Diameter at Breast Height $) \geq 40 \mathrm{~cm}$ (1.3 $\mathrm{m}$ above the ground) were measured. All trees were botanically identified and spatially located by means of geographical coordinates obtained with GPS Garmin 60s.

The selected species are dominant on studying area, presenting the highest values of importance in the forest (Péllico Netto et al., 
2017). These species are widely traded in Amazon region due to characteristics that suit the tropical timber market (IBAMA, 1997; Ferreira \& Hopkins, 2004; Rivera-Martín, PeñuelaMora, Rojas, \& Jaramillo, 2013). As common features, these species have predominantly wind dispersal syndrome and occur in "terrafirme" forests, grown under nutrient-deficient soils (Oliveira \& Mori, 1999; Ribeiro et al., 1999; Ferraz, Leal Filho, Imakawa, Varela, \& Piña Rodrigues, 2004; Laurance et al., 2004), being often cited as the largest trees in the Amazon forest (Guillaumet, 1987; Oliveira \& Mori, 1999).

Astronium lecointei has irregular fruiting, with numerous fruits, which are small and easily dispersed by wind (Ferraz et al., 2004); it is cited as the highest species in the studying area (Cysneiros, Pelissari, Machado, Figueiredo Filho, \& Souza, 2017). Dinizia excelsa fruits are indehiscent, measuring up to $35 \mathrm{~cm}$ in length, with the wind and gravity acting on the primary dispersion, where most of the seeds are lost while still green due to the attack of parrots and monkeys (Dick, Etchelecu, \& Austerlitz, 2003). The fruits of Peltogyne paniculata are dehiscent, measuring up to $5 \mathrm{~cm}$ in length, which, due to animal predation, adopt a high seed production as regeneration strategy, where barochoric and zoochoric dispersion may occur (Rivera-Martín et al., 2013).

Data analysis: To verify possible influences of first-order factors on the species distribution, density maps were constructed used the Kernel estimator (Pottker et al., 2016). Inhomogeneous Ripley's K-function was used for the spatial distribution patterns analysis of the species by means of second-order factors (Baddeley, Moller, \& Waagepetersen, 2000), considering a $250 \mathrm{~m}$ influence radius, through estimator and edge correction presented by Ripley (1977). This function was applied for data and non-stationary process, common in natural forests where the tree species presents intense spatial variability (Baddeley et al., 2000; Baddeley \& Turner, 2005; Pottker et al., 2016).

$$
\widehat{K}_{\text {inhom }(r)}=\sum_{i=1}^{n} \sum_{j=1}^{n} \frac{P_{i j}(r)}{\lambda\left(s_{i}\right) \lambda\left(s_{j}\right)}
$$

Where: $\hat{K}_{\text {inhom }(r)}=$ inhomogeneous K-function; indicator function; $\lambda=$ first-order intensity of the events and ; and $r=$ distance vector.

$\mathrm{K}$-function has as main advantage the possibility of evaluating the spatial patterns of a series of points in different scales, varying the radius of the formed circles (Batista \& Maguire, 1998; Capretz et al., 2012). This function considers as null hypothesis $\left(\mathrm{H}_{0}\right)$ the complete spatial randomness (CSR) of a series of points. Thus, the spatial pattern is classified as random, if the observed values $(\hat{L}(r))$ are within the limits of the reliable envelopes; aggregate, when outside the reliable envelopes and with positive values; and regular, when outside the envelopes and with negative values (Batista \& Maguire, 1998; Capretz et al., 2012).

$\mathrm{K}$-function is described by a simple quadratic equation $(K(r))$, although its transformation to linear form $(\hat{L}(r))$ results in variance stabilization and better graphic interpretation of spatial patterns (Batista \& Maguire, 1998). A total of 1000 Monte Carlo simulations were used for construction of the envelopes ( $\alpha=$ $0.01)$. For this, the analyses were performed in R 3.3.2 program (R Core Team, 2017) with the Spatstat package (Baddeley \& Turner, 2005).

Statistics derived from the inhomogeneous K-function in its bivariate form (Kcross.inhom) were used to assessment of spatial interactions (Baddeley et al., 2000). This function is a generalization of the function Kcross to include an adjustment for spatially inhomogeneous intensity, similar to function Kinhom (Moller \& Waagepetersen, 2003). Species density maps were made by Kernel estimator in raster format and submitted to correlation tests to verify the overlap or segregation of habitats. Thus, the influence of habitat on species spatial interactions of the species was verified. 


\section{RESULTS}

Spatial distribution: The species presented distinct spatial patterns, with visible separation between the nuclei of greater density and aggregation (Fig. 1). Density map of Astronium lecointei showed highest concentration of high- and very high-density classes in the Western and Southern portions. For Dinizia excelsa, a greater area extension was observed for the low- and very low-density classes, with the highest density in the East portion, whereas for Peltogyne paniculata, a high fragmentation of density classes was noted along of the study area surface.

Confidence envelopes evidenced distance-dependent spatial patterns generated by second-order factors (Fig. 2). The species Astronium lecointei presented aggregation at distances (r) close to 50 y $120 \mathrm{~m}$. On the other hand, Dinizia excelsa had spatial randomness for all the analyzed distances, while Peltogyne paniculata showed a greater aggregation in relationship to the other species, with significance of the aggregate pattern of $10 \mathrm{~m}$ to $120 \mathrm{~m}$ distance.

Spatial interactions: The analysis of the interspecific spatial associations of the three dominant species indicated the occurrence of weak and statistically non-significant interactions $(\alpha=0.01)$. When comparing the population of Dinizia excelsa with the other species (Fig. 3A, Fig. 3C), negative interactions were
(A) Astronium lecointei

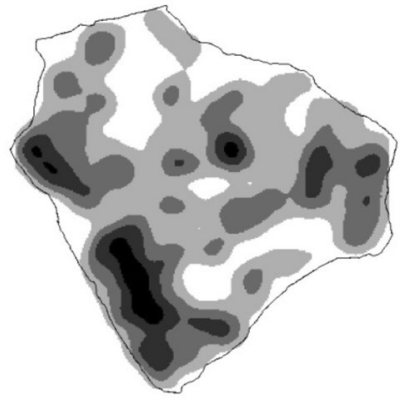

(B) Dinizia excelsa
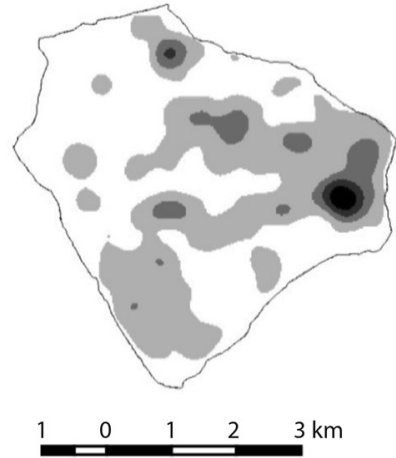

Species density

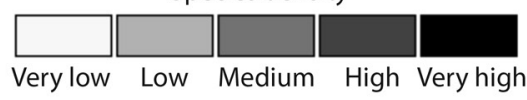

(C) Peltogyne paniculata
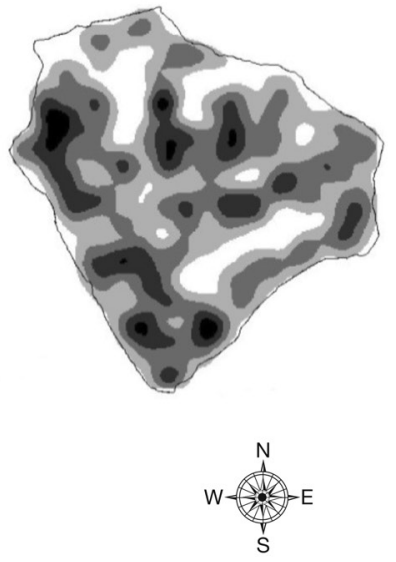

Fig. 1. Density maps of tree spatial dispersion in three species of the forest area.

(A) Astronium lecointei

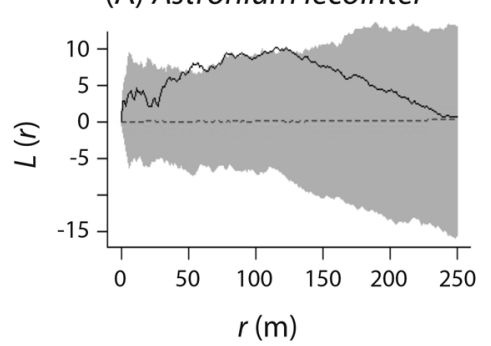

(B) Dinizia excelsa

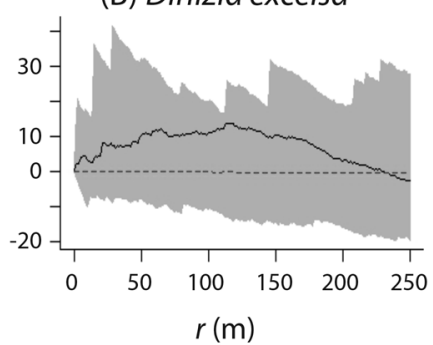

(C) Peltogyne paniculata

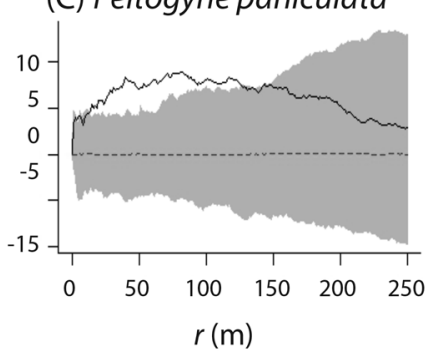

Fig. 2. Confidence envelopes generated by the inhomogeneous $\mathrm{K}$-function for the study species populations, where: $\mathrm{L}=$ univariate inhomogeneous $\mathrm{K}$-function in linear form, and $\mathrm{r}=$ distance vector in meters. 
(A)

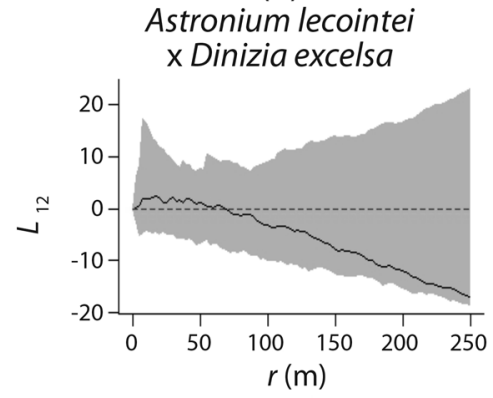

(B)

Astronium lecointei x Peltogyne paniculata

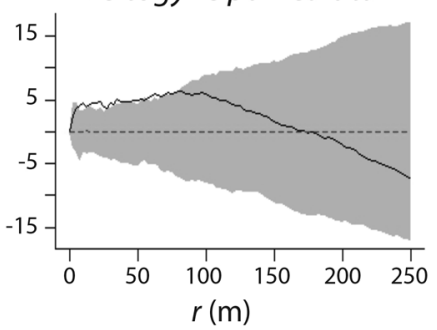

(C)

Dinizia excelsa

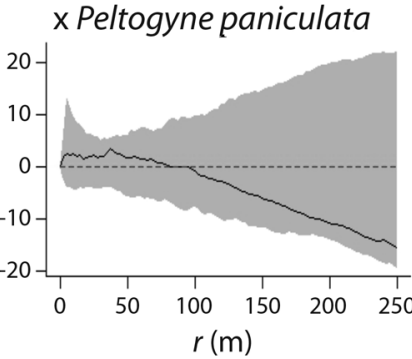

Fig. 3. Confidence envelopes generated by the bivariate inhomogeneous $\mathrm{K}$-function to analyze interspecific population interactions, $\mathrm{L}_{12}=$ bivariate inhomogeneous $\mathrm{K}$-function in linear form.

more expressive, although not significant. Significance was only obtained between Astronium lecointei and Peltogyne paniculata at distances less than $75 \mathrm{~m}$ (Fig. 3B). The positive and significant interaction indicates a tendency of attraction between the populations, providing evidence on the proximity of niches of these species.

A strong positive correlation was obtained between density maps of the species Astronium lecointei and Peltogyne paniculata (0.762), indicating the overlap of their habitats. On the other hand, Dinizia excelsa species showed a weak correlation with Astronium lecointei (0.321) and Peltogyne paniculata (0.385), suggesting a separation between habitats of these species or distinct preferences by environmental conditions.

\section{DISCUSSION}

Spatial distribution - First-order factors: Spatial differences in the dispersion and aggregation of species can be explained by first-order factors. Astronium lecointei species is generalist regarding soil and topography (Figueiredo, Venticinque, Figueiredo, \& Ferreira, 2015), and it occurs in the studied area in aggregated form and widely distributed. Likewise, Peltogyne paniculata frequently appears in inland forests (Ribeiro et al., 1999), of nutrient-poor and sandy soils (Laurance et al., 2004), which are predominant characteristics in the study area, providing formation of dense and widely distributed clusters. With an incidence restricted to plateaus and clayey soils (Ribeiro et al., 1999; Mesquita, Ferraz, \& Camargo, 2007), Dinizia excelsa showed the lowest dispersion in the area, with few aggregation nuclei, indicating a possible influence of the habitat specificity in its distribution.

Spatial distribution - Second-order factors: The spatial aggregation pattern found for Astronium lecointei and Peltogyne paniculata is predominant for tropical trees (Hubbell, 1979; Fangliang et al., 1997; Condit et al., 2000; Lan et al., 2012; Rockwell et al., 2017). This pattern seems to be related to the autecological characteristics of the species on a local scale (Réjou-Méchain et al., 2011) and may be a consequence of the dispersal limitation (Condit et al., 2000; Seidler \& Plotkin, 2006).

An explanation for aggregate spatial patterns derived from second-order factors is related to biotic features, such as dispersal syndrome and limitation (Seidler \& Plotkin, 2006). This explanation is confirmed by comparing the two aggregate species of the present study, since the characteristics of the dispersal syndrome of Astronium lecointei favor its greater dispersion in the forest, reducing, therefore, the aggregation in relation to Peltogyne paniculata (Condit et al., 2000; Thomson, Moles, Auld, \& Kingsford, 2011).

For Dinizia excelsa, other processes seem to influence the random pattern derived from 
second-order factors, since according to Odum (2010) this pattern can occur due to multiple local factors, such as the light requirement of the species, which grows in open areas (Dick, 2001). Due to the need for areas with a high incidence of light, the species depends on the opening of natural clearings to settle in dense forests, the occurrence of which may be spatially conditioned to random factors (Dick, 2001; Asner et al., 2013), thus resulting in the random pattern for the adult trees of the species.

Spatial interactions among populations: Negative interactions among tree populations are similar to competition among species, where the probability of occurrence of a species decreases with increasing abundance of antagonistic species (Volkov et al., 2009). Positive interactions suggest facilitating associations between individuals, with increased probability of occurrence of a species close to a facilitating species (Lan et al., 2012), while the absence of interactions between species is related to niche overlap, suggesting that the trees can share the same space (Higuchi, Silva, van den Berg, \& Daniel, 2011).

In natural forests, positive interactions prevail over negative ones, indicating that this type of association has an important effect on the assemblages of forest species (Callaway, 1995; Lan et al., 2012; Luo, Yu, Chen, Wu, \& Ding, 2012). The evidence of associations between species is best presented at smaller scales, where a high number of positive interactions can be found (Lan et al., 2012). However, the chance of two species interacting reduces when species richness in a community is high (Volkov et al., 2009; Luo et al., 2012). This finding is emphasized by the fact that interspecific relationships are weaker than intraspecific ones in tropical forests (Volkov et al., 2009). In these forests, the decline in associations for mature trees is expected due to local competition (Lan et al., 2012). Therefore, as a mature forest with high species diversity (Péllico Netto et al., 2017), the relationship between adult trees in the study area is less evident, confirming the results found.
Interspecific spatial attraction observed between Astronium lecointei and Peltogyne paniculata at short distances $(<75 \mathrm{~m})$ can be explained by the ecological characteristics of the species, such as microhabitat preference (Wright, 2002; Luo et al., 2012). For tropical trees, partial overlap and segregation increase together with the spatial scale, where species with the same habitat preference tend to associate more frequently at small scales (Luo et al., 2012), suggesting that these species have the same preference for microhabitats. Kernel estimator confirmed the similarity in preferred microhabitats, indicating the overlapping of areas of higher concentration and density of the two species in some places.

The absence of significant interactions for Dinizia excelsa suggests that this species has a preferential habitat which differs from that of Astronium lecointei and Peltogyne paniculata, even though the absence of interactions indicates niche overlap (Higuchi et al., 2011), since trees with similar habitat preference tend to interact (Luo et al., 2012). This finding is reinforced by Kernel estimator, which indicated spatial differences for Dinizia excelsa in relation to the other two species, mainly with respect to areas of higher concentration and density.

Although not significant, the negative interactions of Dinizia excelsa with the other species may evidence the existence of local factors that cause spatial repulsion, such as competition (Connell, 1983; Ewel \& Hiremath, 2005; Volkov et al., 2009). Cited among the Amazon tree species with higher biomass production (Guillaumet, 1987; Oliveira \& Mori, 1999), Dinizia excelsa has a high growth rate (Mesquita et al., 2007) and a large crown that can shade large areas. Astronium lecointei and Peltogyne paniculata need shade in the early stages of life, with an increased need for light throughout their development (Ferraz et al., 2004; Rivera-Martín et al., 2013). These characteristics contribute to the repulsion generated by Dinizia excelsa, which, because of its dense and sparse crown, has an advantage in 
the competition for light and space, mainly with smaller light-demanding species.

Kernel estimator shows an influence of first-order factors on larger scales, indicating preference, overlap or segregation of niches and habitats. In addition, the inhomogeneous $\mathrm{K}$ function evidenced the influence of secondorder factors on smaller scales, such as dispersion and competition for resources, with significance of patterns and interactions only at short distances. Different patterns and spatial interactions were observed for dominant tropical trees - depending on species and scale. The aggregation pattern found for $A$. lecointei and P. paniculata is related to ecological characteristics, such as preferential habitat and dispersal limitation. On the other hand, the random pattern found for D. excelsa is explained by specific features of its establishment, such as the need for clearings due to its light requirement. Considering the interspecific associations of the three species, spatial attraction results from the same preference for microhabitats and repulsion is a consequence of niche segregation.

\section{ACKNOWLEDGMENTS}

We thank the Amata Company for providing the database and the anonymous reviewers for their careful reading of our manuscript.

\section{RESUMEN}

Patrones e interacciones espaciales de especies arbóreas dominantes en un bosque tropical en la Amazonia. El conocimiento de los patrones e interacciones espaciales de las especies arbóreas permite la comprensión de los procesos ecológicos de estructuración espacio-temporal de los bosques tropicales, tornándose imprescindible para el establecimiento de estrategias de conservación y manejo de sus recursos a largo plazo. El objetivo de este estudio fue investigar los patrones y las interacciones espaciales de Astronium lecointei, Dinizia excelsa y Peltogyne paniculata, tres especies arbóreas madereras dominantes en la Selva Nacional del Jamari, Rondônia, Amazonia Brasileña. Para ello, se utilizó el estimador Kernel, con el objetivo de verificar la posible influencia de factores de primer orden en la distribución de las especies. Para el análisis de los patrones e interacciones espaciales de las especies por medio de los factores de segundo orden, se empleó la función $\mathrm{K}$ no homogénea. Los análisis univariados revelaron diferentes patrones espaciales dependientes de la escala para las especies. Agregación relacionada a características ecológicas, como preferencia de hábitat y limitación de la dispersión, fue constatada para A. lecointei y $P$. paniculata. Dinizia excelsa presentó un patrón espacial aleatorio, explicado por características particulares de su establecimiento, como la necesidad de claros debido a sus requisitos lumínicos. Las asociaciones interespecíficas fueron evidenciadas por los análisis bivariados, en que la atracción espacial de las especies resultó de la misma preferencia por micro hábitats y la repulsión fue resultado de la segregación de nichos.

Palabras clave: especies madereras; distribución espacial; asociaciones interespecíficas; estimador de densidad de Kernel; función K no homogénea.

\section{REFERENCES}

Alvares, C. A., Stape, J. L., Sentelhas, P. C., de Moraes Gonçalves, J. L., \& Sparovek, G. (2013). Köppen's climate classification map for Brazil. Meteorologische Zeitschrift, 22(6), 721-728.

Asner, G. P., Kellner, J. R., Kennedy-Bowdoin, T., Knapp, D. A., Anderson, C., \& Martin, R. E. (2013). Forest canopy gaps distributions in the Southern Peruvian Amazon. Plos One, 8, DOI:10.1371/journal. pone. 0060875

Baddeley, A. J., Moller, J., \& Waagepetersen, R. (2000). Spatstat: an R packages for analyzing spatial point patterns. Statistica Neerlandica, 54(3), 329-350.

Baddeley, A., \& Turner, R. (2005). Spatstat: an R package for analyzing spatial point patterns. Journal of Statistical Software, 2(6), 1-42.

Bailey, T. C., \& Gatrell, A. C. (1995). Interactive spatial data analysis. Harlow: Longman Scientific and Technical.

Batista, J. L. F., \& Maguire, D. A. (1998). Modeling the spatial structure of tropical forests. Forest Ecology and Management, 110, 293-314.

Bauch, S., Sills, E., Rodriguez, L. C. E., Mcginley, K., \& Cubbage, F. (2009). Forest Policy Reform in Brazil. Journal of Forestry, 2, 132-138.

Callaway, R. M. (1995). Positive interactions among plants. Botanical Review, 61, 306-349.

Capretz, R. L., Batista, J. L. F., Sotomayor, J. F. M., Cunha, C. R., Nicoletti, M. F., \& Rodrigues, R. R. (2012). Padrão espacial de quatro formações florestais do estado de São Paulo, através da função K de Ripley. Ciência Florestal, 22(3), 551-565. 
Chen, J., \& Bradshaw, G. A. (1999). Forest structure in space: a case study of an old growth spruce-fir forest in Changbaishan Natural Reserve, PR, China. Forest Ecology and Management, 120, 219-233.

Condit, R., Ashton, P., Baker, P., Bunyavejchewin, S., Gunatilleke, S., Gunatilleke, N., Hubbell, S. P., ... Yamakura, T. (2000). Spatial patterns in the distribution of tropical tree species. Science, 288, 1414-1418.

Connell, J. H. (1983). On the prevalence and relative importance of interspecific competition: evidence from field experiments. American Naturalist, 122, 661-696.

Crawley, M. J. (1986). Plant Ecology. Oxford: Blackwell Scientific Publications.

Cysneiros, V. C., Pelissari, A. L., Machado, S. A., Figueiredo Filho, A. \& Souza, L. (2017). Modelos genéricos e específicos para estimativa do volume comercial em uma floresta sob concessão na Amazônia. Scientia Forestalis, 45(114), 295-304.

Dale, M. R. T. (1999). Spatial Pattern Analysis in Plant Ecology. Cambridge: Cambridge University Press.

Dick, C. W. (2001). Genetic rescue of remnant tropical trees by an alien pollinator. Proceedings of the Royal Society of London, 268, 2391-2396.

Dick, C. W., Etchelecu, G., \& Austerlitz, F. (2003). Pollen dispersal of tropical trees (Dinizia excelsa: Fabaceae) by native insects and African honeybees in pristine and fragmented Amazonian rainforest. Molecular Ecology, 12, 753-764.

Ewel, J. J., \& Hiremath, A. J. (2005). Plant-plant interactions in tropical forests. In D. F. R. P. Burselem, M. A. Pinard, \& S. E. Hartley (Eds.), Biotic interactions in the tropics: their role in the maintenance of et species diversity (pp. 3-34). Cambridge: Cambridge University Press.

Fangliang, H., Legendre, P., \& Lafrankie, J. V. (1997). Distribution patterns of tree species in a Malaysian tropical rain forest. Journal of Vegetation Science, $8(1), 105-114$.

Ferraz, I. D. K., Leal Filho, N., Imakawa, A. M., Varela, V. P., \& Piña Rodrigues, F. C. M. (2004). Características básicas para um agrupamento ecológico preliminar de espécies madeireiras da floresta de terra firme da Amazônia Central. Acta Amazonica, 34(4), 621-633.

Ferreira, G. C. \& Hopkins, M. J. G. (2004). Manual de identificação botânica e anatômica - angelim. Belém: Embrapa Amazônia Oriental.

Figueiredo, S. M. M., Venticinque, E. M., Figueiredo, E. O., \& Ferreira, E. J. L. (2015). Predição da distribuição de espécies florestais usando variáveis topográficas e de índice de vegetação no leste do Acre, Brasil. Acta Amazonica, 45(2), 167-174.
Guillaumet, J. L. (1987). Some structural and floristic aspect of the forest. Experientia, 43(3), 241-251.

Harms, E. K., Condit, R., Hubbell, S. P., \& Forster, R. B. (2001). Habitat associations of trees and shrubs in a 50-ha neotropical forest plot. Journal of Ecology, 89(6), 947-959.

Higuchi, P., Silva, A. C., van den Berg, E., \& Daniel, S. P. (2011). Associações espaciais entre indivíduos de diferentes espécies de Miconia spp. Ruiz \& Pav. (Melastomataceae). Revista Árvore, 35(3), 381-389.

Hubbell, S. P. (1979) Tree dispersion, abundance and diversity in a tropical dry forest. Science, 203, 1299-1309.

Hubbell, S. P. (2001). The unified neutral theory of biodiversity and biogeography. Princeton: Princeton University Press.

IBAMA - Instituto Brasileiro do Meio Ambiente e dos Recursos Naturais Renováveis. (1997). Madeiras da Amazônia: características e utilização. Brasília: IBAMA.

Janzen, D. H. (1970). Herbivores and the number of tree species in tropical forests. American Naturalist, 104, 501-528.

Lan, G., Getzin, S., Wiegand, T., Hu, Y., Xie, G., Zhu, H., \& Cao, M. (2012). Spatial distribution and interspecific associations of tree species in a tropical seasonal rain forest of China. Plos One, 7(9), 46074-46080.

Laurance, W. F., Nascimento, H., Laurance, S. G., Condit, R., D'angelo, S., \& Andrade, A. (2004). Inferred longevity of Amazonian rainforest trees based on a long-term demographic study. Forest Ecology and Management, 190, 131-143.

Legendre, P., \& Fortín, M. J. (1989). Spatial pattern and ecological analysis. Vegetatio, 80(2), 107-138.

Luo, Z. R., Yu, M. J., Chen, D. L., Wu, Y. G., \& Ding, B. Y. (2012). Spatial associations of tree species in a subtropical evergreen broad-leaved forest. Journal of Plant Ecology, 5, 1-10.

Matteucci, S. D., \& Colma, A. (1982). Metodologia para el estúdio de la vegetación. Washington: The General Secretarial of The Organization of American States.

Mesquita, M. R., Ferraz, I. D. K., \& Camargo, J. L. C. (2007). Dinizia excelsa Ducke: Morfologia externa de frutos e sementes e mudança foliar da plântula à árvore. Revista Brasileira de Biociências, 5(1), 483-485.

Moller, J., \& Waagepetersen, R. (2003). Statistical inference and simulation for spatial point process. Boca Raton: Chapman and Hall.

Myster, R. W., \& Malahy, M. P. (2012). Testing aggregation hypotheses among neotropical trees and shrubs: 
results from a 50-ha plot over 20 years of sampling. Revista de Biologia Tropical, 60(3), 1015-1023.

Odum, E. P. (2010). Ecologia. Rio de Janeiro: Guanabara, Koogan.

Oliveira, A. A., \& Mori, S. A. (1999). A central Amazonian terra firme forest. High tree species richness on poor soils. Biodiversity and Conservation, 8, 1219-1244.

Péllico Netto, S., Pelissari, A. L., Cysneiros, V. C., Bonazza, M., \& Sanquetta, C. R. (2017). Sampling procedures for inventory of commercial volume tree species in Amazon forest. Anais da Academia Brasileira de Ciências, 89(3), 1829-1840.

Pielou, E. C. (1961). Segregation and symmetry in twospecies populations as studied by nearest- neighbour relationships. Journal of Ecology, 49(2), 255-269.

Pottker, G. S., Oliveira Filho, P. C., Figueiredo Filho, A., \& Dalmaso, C. A. (2016). Padrão espacial de espécies florestais: estudo de caso com Ocotea odorifera (Vell.) Rohwer. Ciência Florestal, 26(4), 1097-1106.

R Core Team. (2017). $R$ : a language and environment for statistical computing. $R$ Foundation for Statistical Computing, Viena, Austria. Retrieved from http:// www.R-project.org/

Réjou-Méchain, M., Flores, O., Bourlandd, N., Doucet, J. L., Fétéké, R. F., Pasquier, A., \& Hardy, O. J. (2011). Spatial aggregation of tropical trees at multiple spatial scales. Journal of Ecology, 99, 1373-1381.

Ribeiro, J. E. L. S., Hopkins, M. J. G., Vicentini, A., Sothers, C. A., Costa, M. A. S., Brito, J. M., Souza, M. A. D., ... Procópio, L. C. (1999). Flora da Reserva Ducke: guia de identificação das plantas vasculares de uma floresta de terra-firme na Amazônia Central. Manaus: INPA.

Ricklefs, R. E., \& Miller, G. L. (2000). Ecology. New York: Freeman \& Co.
Ripley, B. D. (1977). Modeling spatial patterns (with discussion). Journal of the Royal Statistical Society, 39(2), 172-212.

Rivera-Martín, L. E., Peñuela-Mora, M. C., Rojas, E. M. J., \& Jaramillo, M. P. V. (2013). Ecología y silvicultura de especies útiles amazónicas. Amazonas, Colombia: Instituto Amazónico de Investigaciones (IMANI) Universidad Nacional de Colombia.

Rockwell, C. A., Guariguata, M. R., Menton, M., Quispe, E. A., Quaedvlieg, J., Warrem-Thomas, E., Silva, H. F., ... Sala, J. J. Y. (2017). Spatial distribution of Bertholletia excelsa in selectively logged forests of the Peruvian Amazon. Journal of Tropical Ecology, 1, 1-14.

Seidler, T. G., \& Plotkin, J. B. (2006). Seed dispersal and spatial pattern in tropical tree. PLOS Biology, 4(11), 2132-2137.

Silva, K. E., Martins, S. V., Santos, N. T., \& Ribeiro, C. A. A. S. (2009). Padrões espaciais de espécies arbóreas tropicais. In S. E. Martins (Ed.), Ecologia de Florestas Tropicais do Brasil (pp. 216-244). Viçosa: Editora UFV.

Silva, K. E., Martins, S. V., Fortín, M. J., Ribeiro, M. C., Azevedo, C. P., Ribeiro, C. A. A. S., \& Santos, N. T. (2014). Tree species community spatial structure in a terra firme Amazon forest, Brazil. Bosque, 35(3), 347-355.

Thomson, F. J., Moles, A. T., Auld, T. D., \& Kingsford, R. T. (2011). Seed dispersal distance is more strongly correlated with plant height than with seed mass. Journal of Ecology, 99, 1299-1307.

Volkov, I., Banavar, J. R., Hubbell, S. P., \& Maritan, A. (2009). Inferring species interactions in tropical forests. PNAS, 106, 13854-1385.

Wright, S. J. (2002). Plant diversity in tropical forests: a review of mechanisms of species coexistence. Oecologia, 130, 1-14. 